\title{
Plasmonic Coupling Properties in Conductively Touched Metallic Ellipsoidal Dimer and Trimer
}

Mohammed Alsawafta ( $\square$ malsawafta@auk.edu.kw)

American University of Kuwait https://orcid.org/0000-0001-9180-2698

Keywords:

Posted Date: March 24th, 2021

DOI: https://doi.org/10.21203/rs.3.rs-331099/v1

License: (c) (i) This work is licensed under a Creative Commons Attribution 4.0 International License.

Read Full License 


\section{Abstract}

The authors have requested that this preprint be removed from Research Square. 